\title{
THEORETICAL FOUNDATIONS OF USING INFORMATION AND COMMUNICATION TECHNOLOGIES IN PUBLIC ADMINISTRATION DECISION-MAKING PROCESSES
}

\author{
Olha Buhai \\ Postgraduate Student of Educational and Scientific Institute of Public Administration and \\ Civil Service, Taras Shevchenko National University of Kyiv, Ukraine \\ olga.buhay@gmail.com,orcid.org/0000-0002-9223-7851
}

\begin{abstract}
Summary
The purpose of this article is to substantiate the theoretical foundations of using information and communication technologies (hereinafter - ICT) in public administration decision-making processes using the framework of categories and concepts proposed by New Public Management, Joined-up government, Public Value Paradigm, Actor Network Theory and Socio-Technical Systems. The research task is to comprehensively consider the methods, approaches and foundations of using ICT in public administration through these theories. General scientific methods (analysis and synthesis, deduction and induction) as well as the comparative-historical method have been used. Such an approach allows to generalize and comprehend the role and impact of ICT in public administration within the framework of different theories and to offer an empirical application of the developed concepts. Correlation of the considered concepts' theoretical principles with the criteria for public services delivery, the role of citizens, approaches to measuring the performance of public servants makes it possible to conclude the information about the attitudes and requirements for innovations in public administration from the perspective of each of the theories. It can contribute to further study of the ICT's impact on the public administration decision-making processes, predicting the transformational impact of e-governance and theoretical advances empirical application by both public servants and those who hold political positions.
\end{abstract}

Keywords: e-government, innovation, data science, public service, management, performance.

DOI: https://doi.org/10.23856/4618

\section{Introduction}

Public administration decision-making processes is a widely researched topic. In addition, the study of the managerial decision-making phenomenon is interdisciplinary in nature and is studied by representatives of various subject area. The ICT and analytical methods empowerment help to use data in administration decision-making. Rapid progress in data collection and analysis makes it possible to use them in order to build various models in administration decision-making. With this in mind, researchers note that data analysts are increasingly able to influence policy by choosing the research method they prefer (Lavertu, 2016).

Separately, researches emphasize the importance of data quality which are the basis of administration decision-making. Data quality problems are key both for processing them using machine methods and for interpreting the results obtained (Missier et al., 2003).

Theoretical concepts which help to make managerial decisions using ICT make it possible to comprehensively consider the methods, approaches and foundations of e-governance, as well as try to predict the further development and consequences of such a transformation. 


\section{New Public Management \& ICT}

The concept of New Public Management (hereinafter - NPM), which is under increasing criticism and critical rethinking, consider the decision-making on improving the efficiency and effectiveness of public administration (Peters and Waterman, 2004); (Osborne and Gaebler, 1992).

The emergence of NPM set several ambitious goals for governments in public administration and point the right direction for rethinking the public services delivery, defining consumer or client orientated public services, result orientation, greater transparency and openness, responsibility for their decisions, increased competition between private and public delivers of public services as well as decentralization and subsidiarity of decision making.

At one time, NPM proposed structural and organizational changes that were supposed to contribute to public services disaggregation, their decentralization through a broad competition mechanism with the emergence of alternative mechanisms for their delivery, including quasi-markets, when private and public service delivers compete for resources from politicians, which eventually received the definition of "slim State" with "slim Government" through "slim Management" (Cordella and Bonina, 2012).

Thus, the government was seen as an enterprise operating according to business laws: less expenses for more efficiency, focus on the result, not on the process, competition, initiative, etc.

One of the examples confirming the above statement is a study of different European countries local self-governments' needs in financial data for administration decision-making and measuring the actions effectiveness of local politicians and managers. S. Cohen and other researchers investigated how public figures at different levels of local self-government, who prefer the NPM approaches, use information about public funds, revenues and expenditures of public budgets to make decisions, and whether the data generated in accounting and financial programs are sufficient, whether they correspond to the existing request for data-driven decision-making (Cohen et al., 2019).

At the same time, NPM critics noted the excessive commercialization of management processes, their fragmentation and an approach to measuring the effectiveness of administration decision-making and public services delivery, based on improving the processes themselves, without clear answers about the value the achieved indicators have for citizens.

\section{Joined-up government}

A term "joined-up government" emerged as a response to overcoming the fragmentation and decentralization of government decisions within the framework of the NPM concept. The main idea behind the approach rethinking is that public institutions should cooperate, and the idea that one organization (agency, body, etc.) that acts separately can implement the policy is not realistic (Perry, 2004). United by common goals and organizational structure government should form an integrated approach of all management processes coordination that goes beyond parallel bureaucracies and aims at creation a vertically and horizontally integrated public sector (Benouareth and Gacem, 2019).

At the empirical level, co-management refers to the "whole-of-government", the main goal of which is horizontal and vertical relations coordination for reducing internal competition and integrated public service delivery as well as general more economical use of limited resources and increasing economic efficiency by eliminating duplicate responsibilities, creating synergies, bringing together different stakeholders, stimulating teamwork and sharing 
information. Citizens, therefore, should receive better, uninterrupted and holistic access to services, without fragmentation, which is achieved by closer relations between the delivers of these services (Keast, 2011).

\section{Public Value Paradigm}

Public Value Paradigm (hereinafter - PVP) develops the idea of coordinating public administration decision-making and public services delivery through cross-organizational boundaries more (Ling, 2002).

In contrast to individual goals and often opposing judgments, individual goals as a service consumer and object of NPM, public value is the best for the entire group of citizens. Such an awareness radically changes the approach to understanding and designing approaches to administration decision-making and public services delivery.

At the same time, researchers cannot appeal the opinion that public administration relies on the organizational structure and bureaucracy to ensure the homogeneous public services delivery, and, consequently, preserve impartiality and transparency in administration decision-making and public services delivery. Hence, the procedural component of public administration is the result of the need to ensure the impartial implementation of public policy, and therefore, is of the highest value for society (Cordella and Bonina, 2012).

It is worth mentioning that the use of ICT is relevant both within the framework of the NPM and the PVP. At the same time, if we speak about the NPM, ICT is considered as a tool and technology, increasing productivity, efficiency and reducing the cost of a service, but ignoring the impact of technology on the socio-political aspect and public values (Cordella and Bonina, 2012).

In the PVP approach, the use of ICT in public administration is considered as an integral complex of e-governance. While ICT is seen as a "delivery method" of solutions and reforms, meaning a new way of obtaining these data without physical presence with electronic means of identity verification, data and metadata production about the services provided, Cordella emphasizes that this is a very simplified approach that was relevant in the 90s of the XX century (Cordella and Bonina, 2012).

In the modern political and managerial paradigm, the public sector can be focused on the public value creation, and, at the same time, give priority to such management practice that is based on certain goals and focus on efficiency and economy, hence, within the framework of the NPM. At the same time, researchers determine that such public values as equality, trust, accessibility or fairness are difficult to quantify. That is why, within the framework of PVP political aspect should also be taken into consideration itself which contributes to the public administration system (Stoker, 2006).

Awareness of the problem multidimensionality of the effectiveness of decision-making in public administration is a very relevant issue for modern researchers who look for new criteria of transparency and accountability, different from the exclusive and narrow use of economic efficiency indicators.

The increasing use of ICT in public administration has drawn the researchers' attention to the study of technology impact on the public value creation. Kearns (Kearns, 2004), for example, identifies that ICT can create public value in 3 main areas: public service delivery, outcome achievement and public confidence to the institutions.

Heecks (Heecks, 2008) provides a detailed set of indicators for measuring the impact of ICT on public value creation and even suggests that public sector ICT investments can be 
beneficial for citizens and add value to government as a public asset. However, these indicators are based on administrative and economic conditions. Hence, both the social and political consequences of public value creation are measured in terms of administrative and economic criteria in public institutions.

The researchers propose a framework approach that distinguishes public value clusters into those related with management practice and those related with democratic values. The management value group can have parameters and indicators that are commonly used to measure the effectiveness, efficiency and economy of management while the democratic values such as fairness, honesty and trust require additional dimensions. At the same time, researchers admit that such a distinction is factitious and the clusters are likely to overlap. This is especially important when citizens define the public value as an implementation of administrative and economic reforms.

Researches who analyzed the impact of ICT on economic growth gave feasible arguments against using exclusively economic and administrative criteria (Srivastava and Teo, 2008). It is confirmed by the fact that the reforms in the public sector, which are implemented with the help of ICT, are often considered in terms of their impact on socio-political changes.

Cordella and other researchers convincingly argued that the main drivers in the public sector differ from the principles and goals of the business world. Public institutions aim at a variety of goals and are intended to providing citizens with a certain level of expected value, responding to the needs of various groups of society. For example, Proper \& Wilson (Proper and Wilson, 2003) examined performance indicators and their use in health care and education in the United States and the United Kingdom. The researchers concluded that despite the widespread use of performance indicators, "there is little evidence that the use of these indicators improves the efficiency of public services" (Proper and Wilson, 2003: 265).

Janssen and other researchers (Janssen et al., 2004) analyzed 18 international studies on the e-governments effectiveness and found that they all differ in focus and approach which makes it difficult to compare them with each other, and means different understandings of using ICT in public administration.

Without denying the need to measure the effectiveness and efficiency of public administration decision-making we assume that the list of indicators should be expanded and take into account the ways of interaction between the state and citizens, as well as measure and predict the social and political consequences of making certain decisions and reforms, focusing not only on the analysis of costs and incomes, but also evaluating the public value creation.

According to Moore, the central concept of the PVP is a strategic triangle which stipulates that a strategy for public sector organizations must meet three aspects. Firstly, it should be aimed at creating a certain object or process that is valuable in its essence (i.e. to constitute a public value). Secondly, it should be legal and politically stable (i.e. to attract sufficient and long-term support and related resources from both the authorities and other stakeholders. And thirdly, it should be operationally and administratively feasible (i.e. feasible within existing organizational and external capacities) (Moore, 1995).

The main criticism of the PVP and Moore's work as its founder is that the PVP is ambiguous as to whether the concept is an empirical theory or a normative prescription (Alford John and Janine, 2009). Alford and O'Flynn also believe that the PVP can have different meanings: "Firstly, it (Moore's triangle - approx.) can be used to diagnose the current situation (...). Secondly, it can help to structure thoughts about what should actually be ... Thirdly, it offers a set of categories for analyzing the behavior of public managers ..." (Alford John and Janine, 2009). 
In our research we consider the PVP as a system for measuring and managing performance which has empirical value. Kelly, Mulgan and Muers study the public value as the analytical framework for public sector reform. Public value becomes "the value created by the government through the delivery of public services, laws, regulations and other actions," thereby creating a "rough yardstick which can evaluate policies and public institutions' effectiveness" (Kelly et al., 2002a). Public value, as well as private, include benefits derived from personal consumption of public services. While this may be considered a more sophisticated tool for measuring the public services value, this approach is more holistic, because, in this case, a set of consequences from the government is considered, including long-term ones, which, in general, helps to improve political decisions. As a result, it will help to improve the relationship between government and citizens (Kelly et al., 2002b).

Cole and Parston in their book "Unlocking Public Value" presented an approach to assessing the performance of public servants, and proposed a Public Service Value Model (PSVM). According to a new approach, such a model has a simple way to define, measure and increase the value that a public service provides" (Cole and Parston, 2006). While this concept is based on approaches inherent in corporate valuation and is focused on measuring economic performance, it is difficult to note something new or different from the approach proposed by the NPM. That's why it is a relevant question.

Twizeyimana \& Andersson (Twizeyimana and Andersson, 2019) studied the issue of public value as expectations from citizens (according to Moore (Moore, 1995) from the point of view of both developed and developing countries). The study is based not only on measurable indicators, but also aimed at studying changes in the behavior of various actors and how the use of ICT influenced citizens with different social roles (taxpayers, public servants, employees, decision-makers, etc.). The researchers came to the conclusion that regardless of the country's economic development level, the achievement of public value should be understood as the ability of e-governance (governance using ICT) to ensure improved governance, improve the quality of public service delivery and ensure values such as inclusion, democracy, transparency and participation.

Pang and others (Pang et al., 2014) in their turn came to the conclusion that e-government may create the public value through five organizational capabilities: the ability to deliver public services, the ability to involve the public, the ability to co-produce, the ability to create resources and public sector innovativeness.

According to Ndou (Ndou, 2004), the structure of e-governance consists of 3 main components: transformation zones; users, stakeholders and their relationships and areas of e-governance (tools, portals that concern them).

At the same time, the transformation zones are divided into internal, external and relative. Ndou says that internal transformation zones are related to the use of ICT to improve the efficiency of internal functions and management processes. For example, e-governance connects various public institutions structural units or the institutions themselves, thus facilitating the work with information flows. External transformation zones present new opportunities for governments to be more transparent and accountable to citizens and businesses by providing access to more data. Relative transformation zones explain how ICT can lay the fundamental changes in the relationships between citizens and government and affect the democratic process and the very power structure.

Moreover, according to Ndou, there are 4 main groups of stakeholders (users): citizens, enterprises, governments (government agencies and other public institutions, governments of other states) and employees. Electronic transactions and electronic interaction between the 
state (government) and each of the groups constitute the e-government network: G2C, G2B, $\mathrm{G} 2 \mathrm{G}$ and G2E.

Ndou states that there are 3 main areas for implementing e-governance within these transformation zones: e-Administration, e-Citizens and e-Services and e-Society.

Based on the results of 53 researchers works Twizeyimana \& Andersson (Twizeyimana and Andersson, 2019) determine 6 aspects of e-government public value:

1. quality of public service delivery increase;

2. management efficiency improvement;

3. opportunities provided by Open Government (OG);

4. ethical behavior and professionalism improvement;

5. increasing the level of trust and confidence in the government;

6. public value and well-being improvement.

Such variety of public administration aspects using ICT has not only theoretical value, but can also be used in practice to evaluate the achievement of government goals in e-governance. As Moore (Moore, 1995) pointed out, the e-governance policy and implementation can be seen in terms of public value achievement and the e-governance public value should be understood as the impact of ICT on public policy, goals, actions and services for citizens.

Bannister and Conolly studied the relationship between ICT and public service transformation in the context of public value achievement. They note that "transformation" has become an integral part of e-governance discourse. By transformation researchers understand not just changes, but a radical impact on processes and even on public values. At the same time, researchers come to the conclusion that transformation does not always mean transformation for the better, but can also lead to negative consequences (Bannister and Connolly, 2014).

From the point of values view, Bannister and Conolly classify the transformation impact of ICT according to 5 impact directions: scale, scope, integration, speed and capabilities. Moreover, they sum up that not all changes due to the use of ICT are transformational, and where transformations take place, they are not always positive. This is primarily due to the fact that when politicians, practitioners and academics discuss the transformation impact of ICT on public administration they focus on positive changes that ICT adoption can contribute. This group includes techno-optimists who, speaking about the positive impact of ICT, usually only predict it. However, there are also more moderate techno-optimists. Snijkers, for example, noted that there are always conflicts between different values in public administration, and the use of ICT provides new opportunities for their solution. In addition, he is optimistic about the impact of ICT on such a value as privacy. The researcher also states that ICT can be used to create new forms of horizontal control and interaction in the classical Weberian bureaucracy understanding and, accordingly, improve social justice (Snijkers, 2005).

The transformation impact of ICT on government and the impact of technology on public sector values is a potentially powerful tool. It can offer one of the approaches to solving the problem of what constitutes the public administration transformation.

\section{Actor Network Theory}

The approach to studying the influence of e-governance on public administration decision-making through the paradigm of public value is also closely connected with the Actor Network Theory (hereinafter - ANT).

As mentioned above, according to Ndou, the structure of e-government consists of users, stakeholders and their relationships, as well as online tools in various areas of transformation. 
ANT examines the influence of ICT on public administration decision-making precisely from the perspective of influence and mutual influence of all these phenomena. In addition, relationships with actors, who are inanimate, are also investigated within the framework of this theory (Latour, 2005).

ANT is increasingly used to understand the mutual influence of technology and people, including the sphere of public administration. Despite certain limitations, this approach can conceptually be useful for understanding the modern reality complexity, including institutions and organizations' complexity in the public administration system and the active role of technology in this context. Moreover, ANT offers a framework of categories and concepts for understanding what social effects are generated as a result of interactions between different network actors. The key role is that ANT offers such an idea that focuses on the role of technology in social processes formation. And this approach is not only of theoretical value, but can also be useful for practitioners to predict scenarios of medium and long-term results from the use of ICT (e-governance).

\subsection{Actor Network Theory \& Socio-Technical Systems}

Socio-Technical Systems (hereinafter - STS) is also often used to study the interaction between people and technologies and the complexity of their relationship. The main idea of this concept is the complexity of interactions. In our case, such an approach can determine that public administration is a system at national (regional, basic) level, the technical dimensions are ICT, and the social dimensions are the attitude, use and relationships of stakeholders. Studying these components through the lens of the complementarity of all constituents is important for understanding how the system functions (Adamides, 2020); (Beese Jannis et al., 2015).

The STS focuses on the fact that with technological changes, both in private and public organizations, the need to search for personnel with new knowledge and skills, previously unclaimed or non-existent competencies, is becoming very relevant (Sorensen and Paulsson, 2020).

The concept of social and technical transitions, which has been actively studied since the 1990s (Geels, 2010), attracts special attention of researchers within the STS. As part of these transitions, "carriers" become dominant over time and begin to manage systems and shape social and political changes. The development of the motor industry (Urry, 2004) and the emergence of a microprocessor (Markoff, 1996) had such an impact, which influenced not only the way of moving and processing information, but also caused dramatic changes in all spheres of life. The STS developers are of the opinion that the public relations digitalization, which is taking place nowadays, will have the same impact (Sorensen and Paulsson, 2020).

ANT is based both on the STS theory (Cresswell, 2010) and on inanimate and their influence on social processes. Thus, the actor is defined as "the source of the action, regardless of whether he/she is a person or inanimate". The peculiarity of this theory is that inanimate (for example, technologies) can have an impact both on a person and social processes. But since such an influence is carried out and is less argued inanimate can also be considered as something that have freedom of action (Mol, 1999); (Doolin B and A, 2012).

However, an actor can interact with other actors and networks that, in fact, give the actor the opportunity to act. This is due to the fact that the interaction is happening by different actors at a certain time and in a certain place (Latour, 2005); (Law, 1992).

Thus, the ANT approach is based on technology that arises from social interests (e.g., economic, professional) and, accordingly, has the potential to form social interactions (Latour, 2005). 
Since the emergence of ANT in the 1980s, Latour and Law are the most influential thinkers in this area. They have often been criticized for their radical approach to defining actors, however, with the subsequent rapid ICT development the theory is increasingly becoming popular in the context of studying the processes of using technologies in public administration.

\section{Innovations}

Considering all the theoretical approaches mentioned above, researchers are looking not only for ways to comprehend and conceptualize modern public administration, but also answers about the ICT's role in other spheres of life. This is directly related to the study of the readiness and need for innovations in public administration, their capabilities and limitations and objectives that can be solved.

Public figures increasingly esteem innovations as the basis for organizational changes, a tool for adapting to uncertainty, and an opportunity to increase citizens' confidence in government (Damanpour and Schneider, 2009). A. Peralta and L. Rubalcaba consider the concept of management, that is leading in a particular country at the time of innovations implementation, to be an important predictor of readiness for innovations in public administration. At the same time, these researchers also developed a methodology to determine the impact on the willingness to innovate and other criteria which consists of habits, expected efficiency from implementation, duration of production and amount of effort required, cost, social impact, hedonic motivation, favorable conditions, as well as age, gender, and experience in public administration. Innovations in general and their predictors, implementation results, as well as the innovators decision to use technology, tools or innovation practices in public administration are studied in more detail in the framework of the so-called services innovation studies (Peralta and Rubalcaba, 2021).

Innovation in public administration is a set of visible and invisible transformations that occur with the use of technological tools and developments. Moreover, the tools and developments are not limited only to software and physical equipment, but also include the practices, methods, skills, knowledge and skills necessary to achieve the goal (Peralta and Rubalcaba, 2021).

Table 1

Correlation of approaches to innovation in accordance with public administration concepts

\begin{tabular}{|c|l|l|l|l|l|}
\hline $\begin{array}{c}\text { Public } \\
\text { administration } \\
\text { concept }\end{array}$ & $\begin{array}{l}\text { Theoretical } \\
\text { principles }\end{array}$ & $\begin{array}{l}\text { Criteria of } \\
\text { public service } \\
\text { delivery }\end{array}$ & Citizens` role & $\begin{array}{l}\text { Public } \\
\text { servants } \\
\text { effectiveness } \\
\text { measurement }\end{array}$ & $\begin{array}{c}\text { Approach } \\
\text { to innovations }\end{array}$ \\
\hline 1 & 2 & 3 & 4 & 5 & 6 \\
\hline $\begin{array}{l}\text { New Public } \\
\text { Management }\end{array}$ & $\begin{array}{l}\text { Market rela- } \\
\text { tions, competi- } \\
\text { tion, hierarchy, } \\
\text { public-private } \\
\text { partnership }\end{array}$ & $\begin{array}{l}\text { Market } \\
\text { value, service } \\
\text { competition, } \\
\text { efficiency }\end{array}$ & $\begin{array}{l}\text { Consumer who } \\
\text { freely choose } \\
\text { among various } \\
\text { competitive } \\
\text { offers }\end{array}$ & $\begin{array}{l}\text { Advantage to } \\
\text { economic indi- } \\
\text { cators (savings, } \\
\text { cost efficiency, } \\
\text { revenue } \\
\text { increase }\end{array}$ & $\begin{array}{l}\text { Introducing } \\
\text { new products } \\
\text { to achieve } \\
\text { economic effi- } \\
\text { ciency. Public } \\
\text { servants intro- } \\
\text { duce, people } \\
\text { taking political } \\
\text { capacity make } \\
\text { decisions to use } \\
\text { innovations }\end{array}$ \\
\hline
\end{tabular}


Table 1 (Continued)

\begin{tabular}{|c|c|c|c|c|c|}
\hline 1 & 2 & 3 & 4 & 5 & 6 \\
\hline $\begin{array}{l}\text { Joined-up } \\
\text { government }\end{array}$ & $\begin{array}{l}\text { Cooperation, } \\
\text { coordination, } \\
\text { single-level, } \\
\text { vertical and } \\
\text { horizontal } \\
\text { integration }\end{array}$ & $\begin{array}{l}\text { Simplicity, } \\
\text { single-window } \\
\text { system, service } \\
\text { integration }\end{array}$ & $\begin{array}{l}\text { Segmented user } \\
\text { groups accord- } \\
\text { ing to various } \\
\text { criteria }\end{array}$ & $\begin{array}{l}\text { Economic } \\
\text { criteria and } \\
\text { citizens' } \\
\text { engagement } \\
\text { assessment }\end{array}$ & $\begin{array}{l}\text { Priority is } \\
\text { given to shar- } \\
\text { ing innova- } \\
\text { tions, mutual } \\
\text { mechanisms }\end{array}$ \\
\hline $\begin{array}{l}\text { Public Value } \\
\text { Paradigm }\end{array}$ & $\begin{array}{l}\text { Multidimen- } \\
\text { sionality, trust, } \\
\text { value approach, } \\
\text { stability, legiti- } \\
\text { macy }\end{array}$ & $\begin{array}{l}\text { Democracy } \\
\text { and efficiency, } \\
\text { priority of the } \\
\text { public over } \\
\text { the individual, } \\
\text { inclusion, sim- } \\
\text { plicity }\end{array}$ & $\begin{array}{l}\text { Co-developer } \\
\text { (co-author) of } \\
\text { solutions }\end{array}$ & $\begin{array}{l}\text { Multicriteria } \\
\text { approach with } \\
\text { the assessment } \\
\text { of public value } \\
\text { achievement }\end{array}$ & $\begin{array}{l}\text { Innovation } \\
\text { must serve the } \\
\text { achievement of } \\
\text { public values }\end{array}$ \\
\hline $\begin{array}{l}\text { Actor Network } \\
\text { Theory }\end{array}$ & $\begin{array}{l}\text { Networks } \\
\text { (formal and } \\
\text { informal), hori- } \\
\text { zontal relations, } \\
\text { multicentricity, } \\
\text { interactions, } \\
\text { inanimate actor }\end{array}$ & $\begin{array}{l}\text { Impact assess- } \\
\text { ment, incl. } \\
\text { long-term one, } \\
\text { assessment of } \\
\text { the role of each } \\
\text { of the actors }\end{array}$ & $\begin{array}{l}\text { Actor, who } \\
\text { influences } \\
\text { every network } \\
\text { link by making } \\
\text { decisions or } \\
\text { performing an } \\
\text { action } \\
\end{array}$ & $\begin{array}{l}\text { Time and inter- } \\
\text { action intensity } \\
\text { assessment } \\
\text { in correlation } \\
\text { with expected / } \\
\text { obtained result }\end{array}$ & $\begin{array}{l}\text { A person devel- } \\
\text { ops technology, } \\
\text { and technology } \\
\text { affects the per- } \\
\text { son and social } \\
\text { relations }\end{array}$ \\
\hline $\begin{array}{l}\text { Socio- } \\
\text { Technical } \\
\text { Systems }\end{array}$ & $\begin{array}{l}\text { Multilevel } \\
\text { interactions, } \\
\text { complexity of } \\
\text { systems }\end{array}$ & $\begin{array}{l}\text { Complexity } \\
\text { and structure } \\
\text { of business } \\
\text { processes }\end{array}$ & $\begin{array}{l}\text { Citizens form } \\
\text { a system that } \\
\text { is in complex } \\
\text { interaction with } \\
\text { the systems of } \\
\text { government, } \\
\text { state, etc. }\end{array}$ & $\begin{array}{l}\text { Rethinking of } \\
\text { public service } \\
\text { delivery pro- } \\
\text { cesses in order } \\
\text { to meet the } \\
\text { citizens' needs }\end{array}$ & $\begin{array}{l}\text { A person devel- } \\
\text { ops technology, } \\
\text { and technology } \\
\text { affects the per- } \\
\text { son and social } \\
\text { relations }\end{array}$ \\
\hline
\end{tabular}

Source: author's development

\section{Conclusions}

To sum up, the article substantiates theoretical foundations of using information and communication technologies in public administration decision-making processes based on numerous theories:

- strengths and weaknesses of key theoretical approaches are defined: nonconformity of New Public Management to modern demand for public administration and a simplified approach to the role of ICT, both in decision-making and in public service delivery; the requirement for coordination between various public organizations, which is the central idea of the Joined-up government, is a part of other concepts, and at the current level of ICT development is considered as a basic necessity for modern management models. Within the framework of the Public Value Paradigm the attention is paid to the definition and creation of public value as the main task of public administration. At the same time, the markers that could be indicators of the public value achievement haven't studied sufficiently. The Actor Network Theory defines the information and communication technologies as actors that, being created by man, acquire the ability to influence both the way policies are formed and the ways and approaches to public 
service delivery. At the same time, although the theory of Socio-Technical Systems does not emphasize the inanimate actors` subjectivity, it considers technologies as predictors and factors of socio-political and socio-cultural transformations;

- the priority research areas related to determining the ICT transformational or auxiliary influence on decision-making in public administration, forecasting the spread of e-governance at various levels of territorial development are singled out. Other issues that will be the next scientific research are technologies development and an increase in the amount of data that can be used both for making management decisions and for improving the quality of public service delivery, as well as the ICT impact on the political landscape and public administration in general;

- the possibilities for innovative approaches introduction to make decisions in public administration within the framework of various theoretical concepts are outlined. It may have empirical value for ICT implementation at various levels of territorial development.

\section{References}

Adamides, E. D. (2020). Activity-based analysis of sociotechnical change [Article]. Systems Research and Behavioral Science, 37(2), 223-234. https://doi.org/10.1002/sres. 2616

Albrechtslund, A. (2007). Ethics and technology design. In (Vol. 9, pp. 63-72): Ethics Inf Technol.

Alford John, \& Janine, O. F. (2009). Making Sense of Public Value: Concepts, Critiques and Emergent Meanings. In (Vol. 32, pp. 171-191). International Journal of Public Administration. Bannister, F., \& Connolly, R. (2014). ICT, public values and transformative government: A framework and programme for research [Article]. Government Information Quarterly, 31(1), 119-128. https://doi.org/10.1016/j.giq.2013.06.002

Beese Jannis, Haki Kazem, \& Stephan, A. (2015). On the Conceptualization of Information Systems as Socio-Technical Phenomena in Simulation-Based Research 2015 International Conference on Information Systems (ICIS 2015), Fort Worth, TX. https://www.researchgate.net/ publication/285152964_On_the_Conceptualization_of_Information_Systems_as_Socio-Technical_Phenomena_in_Simulation-Based_Research

Benouareth, C. E., \& Gacem, M. (2019). UNDERSTANDING "JOINING-UP-GOVERNMENT" REFORMS IN ANGLO-SAXON NATIONS FROM A CULTURAL POINT OF VIEW [Article]. Voprosy Gosudarstvennogo I Munitsipalnogo Upravleniya-Public Administration Issues(5), 27-45. https://doi.org/10.17323/1999-5431-2019-0-5-27-45

Cohen, S., Rossi, F. M., Caperchione, E., \& Brusca, I. (2019). Local government administration systems and local government accounting information needs: is there a mismatch? [Article]. International Review of Administrative Sciences, 85(4), 708-725. https:// doi.org/10.1177/0020852317748732

Cole, M., \& Parston, G. (2006). Unlocking Public Value: A New Model For Achieving High Performance In Public Service Organizations.

Cordella, A., \& Bonina, C. M. (2012). A public value perspective for ICT enabled public sector reforms: A theoretical reflection [Article]. Government Information Quarterly, 29(4), 512-520. https://doi.org/10.1016/j.giq.2012.03.004

Cresswell, K. M., Worth, A., Sheikh, A. (2010). Actor-Network Theory and its role in understanding the implementation of information technology developments in healthcare. In. BMC Medical Informatics and Decision Making. 
Damanpour, F., \& Schneider, M. (2009). Characteristics of Innovation and Innovation Adoption in Public Organizations: Assessing the Role of Managers [Review]. Journal of Public Administration Research and Theory, 19(3), 495-522. https://doi.org/10.1093/jopart/mun021 Doolin B, \& A, L. (2012). To Reveal is to Critique: Actor-Network Theory and Critical Information Systems Research. In (Vol. 17(2):69-78). Journal of Information Technology.

Du Gay, P. (1994). Making up Managers: Bureaucracy, Enterprise and the Liberal Art of Separation. In (Vol. 45, pp. 655-674): The British Journal of Sociology.

Geels, F. W. (2010). Ontologies, socio-technical transitions (to sustainability), and the multi-level perspective [Article]. Research Policy, 39(4), 495-510. https://doi.org/10.1016/j. respol.2010.01.022

Gruening, G. (2001). Origin and theoretical basis of new public management. In (Vol. 4, pp. 1-25): International Public Management Journal.

Heeks, R. (2008). Benchmarking e-Government: Improving the national and international measurement, evaluation and comparison of e-Government. In (pp. 257-301): Evaluating Information Systems.

Hood, C. C., \& Margetts, H. Z. (2007). The tools of government in the digital age. In. Basingstoke, UK, Macmillan International Higher Education.

Janssen, D., Rotthier, S., \& Snijkers, K. (2004). If you measure it they will score: An Assessment of international government benchmarking. In (Vol. 9, pp. 121-130): Information Polity.

Kearns, I. (2004). Public value and e-government. Institute for Public Policy Research.

Keast, R. (2011). Joined-Up Governance in Australia: How the Past Can Inform the Future. In (Vol. 34, pp. 221-231). International Journal of Public Administration: International Journal of Public Administration.

Kelly, G., Mulgan, G., \& Muers, S. (2002a). Creating Public Value: An Analytical Framework for Public Service Reform. In. Discussion paper preparedby the Cabinet Office Strategy Unit, United Kingdom.

Kelly, G., Mulgan, G., \& Muers, S. (2002b). Creating Public Value: AnAnalytical Framework for Public Service Reform. In. Discussion paper preparedby the Cabinet Office Strategy Unit, United Kingdom.

Latour, B. (2005). Reassembling the social: An introduction to actor-network-theory. Oxford university press.

Lavertu, S. (2016). We All Need Help: "Big Data" and the Mismeasure of Public Administration [Article; Proceedings Paper]. Public Administration Review, 76(6), 864-872. https:// doi.org/10.1111/puar.12436

Law, J. (1992). Notes on the theory of the actor-network: Ordering, strategy, and heterogeneity. In (Vol. 5, pp. 379-393). Systems Practice.

Ling, T. (2002). Delivering joined-up government in the UK: Dimensions, issues and problems [Article]. Public Administration, 80(4), 615-642. https://doi.org/10.1111/1467-9299.00321

Markoff, J. (1996). The microprocessor's impact on society [Article]. Ieee Micro, 16(6), 54-59. https://doi.org/10.1109/40.546565

Missier, P., Lalk, G., Verykios, V., Grillo, F., Lorusso, T., \& Angeletti, P. (2003). Improving data quality in practice: A case study in the Italian Public Administration [Article]. Distributed and Parallel Databases, 13(2), 135-160. https://doi.org/10.1023/a:1021548024224

Mol, A. (1999). Ontological politics. A word and some questions. In (Vol. 47(1_suppl), pp. 74-89). The sociological review.

Moore, M. H. (1995). Creating public value: Strategic management in government. Harvard university press. 
Ndou, V. (2004). E-government for developing countries: Opportunities and challenges. In (Vol. 18): The Electronic Journal of Information Systems in Developing Countries.

Osborne, D., \& Gaebler, T. (1992). Reinventing government: How the entrepreneurial spirit is transforming the public sector. Addison-Wesley. https://doi.org/10.1002/pam.4050130113

Pang, M. S., Lee, G., \& DeLone, W. H. (2014). IT resources, organizational capabilities, and value creation in public sector organisations: A public-value management perspective In (Vol. 29, pp. 187-205): Journal of Information Technology.

Peralta, A., \& Rubalcaba, L. (2021). How Governance Paradigms and Other Drivers Affect Public Managers' Use of Innovation Practices. A PLS-SEM Analysis and Model [Article]. Mathematics, 9(9), 28, Article 1055. https://doi.org/10.3390/math9091055

Perry. (2004). Joined-up government in the western world in comparative perspective: A preliminary literature review and exploration. In (Vol. 14, pp. 103-138): Journal of Public Administration Research and Theory.

Peters, T., \& Waterman, R. (2004). In Search of Excellence: Lessons From America's Best-Run Companies. HarperCollins. https://doi.org/10.2307/2393015

Pollit, C., \& Bouchaert, G. (2004). Public management reform. In: Oxford University Press.

Proper, C., \& Wilson, D. (2003). The use and usefulness of performance measures. In (Vol. 19, pp. 250-267). OxfordReview of Economic Policy.

Snijkers, K. (2005). E-government: ICT from a public management perspective In 13th annual NISPACEE conference.

Sorensen, C. H., \& Paulsson, A. (2020). Contextualizing Policy: Understanding Implementation under Socio-technical Transitions [Article]. International Journal of Public Administration, 43(12), 1055-1067. https://doi.org/10.1080/01900692.2019.1665067

Srivastava, S. C., \& Teo, T. S. H. (2008). The relationship between e-government national competitiveness: The moderating influence of environmental factors. In (Vol. 23, pp. 73-94): Communications of the Association for Information Systems.

Stoker, G. (2006). Public Value Management: A New Narrative for Networked Governance? In (Vol. 36, pp. 41-57). The American Review of Public Administration.

Twizeyimana, J. D., \& Andersson, A. (2019). The public value of E-Government - A literature review [Review]. Government Information Quarterly, 36(2), 167-178. https://doi.org/10.1016/j. giq.2019.01.001

Urry, J. (2004). The 'system' of automobility [Article]. Theory Culture \& Society, 21(4-5), 25-+. https://doi.org/10.1177/0263276404046059 